\title{
A SUMMARY OF THE REPORT ON PROSPECTS FOR PYROLYSIS TECHNOLOGIES IN MANAGING MUNICIPAL, INDUSTRIAL, AND DEPARTMENT OF ENERGY CLEANUP WASTES*
}

Prepared for the Northeast Waste

Management Enterprise

by

Sheldon J. Reaven

State University of New York at Stony Brook

August 1994

Brookhaven National Laboratory Associated Universities, Inc. Upton, NY 11973
Long Island Research Institute

110 Lake Avenue South Suite 35 Nesconset, NY 11767

*Work performed under Contract No. DE-AC02-76CHOOO6 with the U.S. Department of Energy 


\section{DISCLAMMER}

This report was prepared as an account of work sponsored by the United States Government. Neither the United States nor the United States Department of Energy, nor any of their employees, nor any of their contractors, subcontractors, or their employees, makes any warranty, express or implied, or assumes any legal liability or responsibility for the accuracy, completeness, or usefulness of any information, apparatus, product or process disclosed, or represents that its use would not infringe privately owned rights. 


\section{DISCLAIMER}

Portions of this document may be illegible in electronic image products. Images are produced from the best available original document. 
A SUMMARY OF THE REPORT ON PROSPECTS FOR PYROLYSIS TECHNOLOGIES

IN MANAGING MUNICIPAL, INDUSTRIAL, AND DEPARTMENT OF ENERGY CLEANUP WASTES

\section{Table of Contents}

PREFACE $\ldots \ldots \ldots \ldots \ldots \ldots \ldots \ldots \ldots \ldots \ldots \ldots \ldots \ldots \ldots \ldots \ldots$

SUMMARY $\ldots \ldots \ldots \ldots \ldots \ldots \ldots \ldots \ldots \ldots \ldots \ldots \ldots \ldots \ldots \ldots \ldots \ldots \ldots$

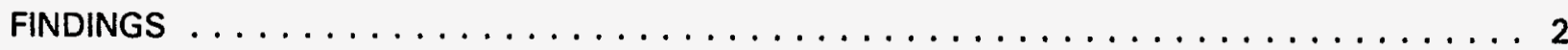

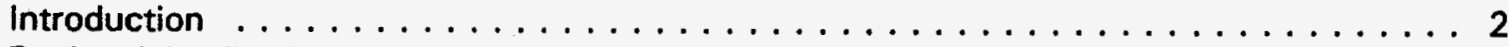

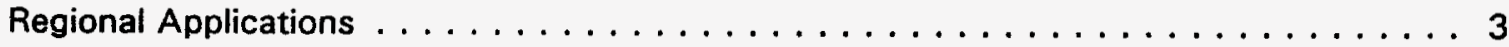

Municipal Solid Wastes $\ldots \ldots \ldots \ldots \ldots \ldots \ldots \ldots \ldots \ldots \ldots$

Industrial Wastes $\ldots \ldots \ldots \ldots \ldots \ldots \ldots \ldots \ldots \ldots$

Tires ............................... 7

Hospital Wastes . . . . . . . . . . . . . . . . . . 8

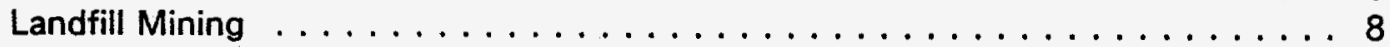

Energy Applications . . . . . . . . . . . . . . . . . . 8

Factors Affecting Regional Adoption $\ldots \ldots \ldots \ldots \ldots \ldots \ldots \ldots \ldots \ldots$

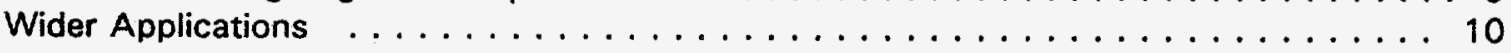

DOE and Other Federal Site Cleanup . . . . . . . . . . . . . . . 10

National and International Opportunities for Pyrolysis and Related

Environmental Technologies . . . . . . . . . . . . . . . . . . . 11

RECOMMENDATIONS $\ldots \ldots \ldots \ldots \ldots \ldots \ldots \ldots \ldots \ldots \ldots \ldots \ldots$

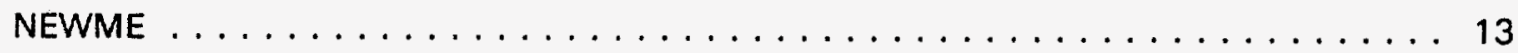

Brookhaven National Laboratory and its Academic and Industrial Partners . . . . . . . 14

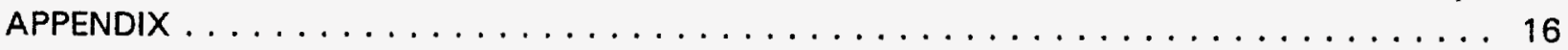

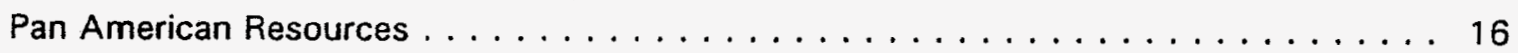

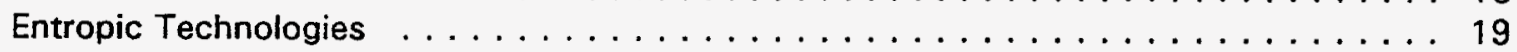

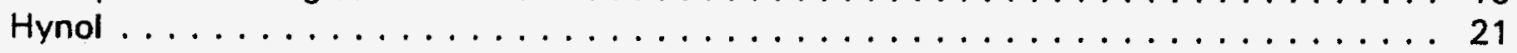

Conrad/Tuttle Technologies . . . . . . . . . . . . . . . . . 24 


\section{TABLES}

Table 1: Summary Comparison of MSW Pyrolysis Processes . . . . . . . . . . . . . . 4

Table 2: Targets of Opportunity for Pyrolysis in the Municipal Solid Waste Stream . . . . . . . 5 


\section{PREFACE}

This report on the status and potential of pyrolysis technologies was prepared by Dr. Sheldon Reaven of the University at Stony Brook's Waste Management Institute and College of Engineering for the Northeast Waste Management Enterprise (NEWME). A partnership between industry, federal laboratories, and universities, NEWME was formed to help the U.S. waste management industry become internationally competitive by increasing the economic, commercial, and environmental effectiveness of solid waste management through implementation of new technology. With initial funding from the U.S. Department of Energy (DOE), NEWME is being managed by the Long Island Research Institute in cooperation with Brookhaven National Laboratory (BNL).

Of particular interest to NEWME are problems of solid waste management in densely populated areas of the U.S. and those associated with DOE's waste management and environmental clean-up programs. Pyrolysis is one of the initial technologies chosen for consideration, and Dr. Reaven's paper provides ample justification for its inclusion. It is a widely applicable technology that has, in recent times, been overlooked despite its potential. The analysis and recommendations contained in this paper, and in a more detailed technical report by Professor Reaven, will advance NEWME's consideration of the technology.

As a next step, NEWME intends to invite companies to submit specific proposals for pyrolysis projects on Long Island. Review of these proposals will address such issues as: financial data, relevant regulatory and local government concerns (including implications of the recent Supreme Court ruling on incinerator ash); and remaining barriers to commercialization of the technology. After weighing the relative merits of the different pyrolysis systems in light of these issues, NEWME will decide whether to proceed with a demonstration project.

The characterizations of pyrolysis technologies and the recommendations in this report are those of the author, and do not necessarily reflect the positions or policies of NEWME or of the Long Island Research Institute. 


\section{SUMMARY}

Pyrolysis converts portions of municipal solid wastes, hazardous wastes and special wastes such as tires, medical wastes and even old landfills into solid carbon and a liquid or gaseous hydrocarbon stream. The typical pyrolysis process heats a carbonaceous waste stream to 290 $900^{\circ} \mathrm{C}$ in the absence of oxygen and reduces waste volumes by $90 \%$ and waste weights by $75 \%$. The solid carbon char has existing markets as an ingredient in many manufactured goods and as an adsorbent or filter to sequester certain hazardous waste components. Pyrolytic gases may be burned as fuel by utilities or liquefied for use as chemical feedstocks or constituents of low-pollution motor vehicle fuels.

In the past twenty years, advances in the engineering of pyrolysis systems and in sorting and feeding technologies for solid waste industries have ensured consistent feedstocks and system performance. Some vendors now offer complete pyrolysis systems with performance warranties.

This report analyzes the potential applications of pyrolysis in the Long Island region and evaluates the four most promising pyrolytic systems for their technological and commercial readiness, their applicability to regional waste management needs and their conformity with DOE environmental restoration and waste management requirements. This summary characterizes the engineering performance, environmental effects, costs, product applications and markets for these pyrolysis systems. The full report, Prospects for Pyrolysis Technologies in Managing Municipal, Industrial, and DOE Cleanup Wastes (Reaven, 1994), addresses these issues in greater detail.

After evaluating the economics of specific proposals for applications of these pyrolysis systems in the region, NEWME may develop a tactical plan to demonstrate and commercialize this technology for regional waste management and for DOE environmental restoration programs. Because it can effectively treat those wastes that are inadequately addressed by current systems (e.g., tires, medical wastes, automobile shredder fluff, unrecycled plastics, food wastes and hazardous organic wastes), pyrolysis can play an important complementing role in the region's existing waste management strategy. Its role could be even more significant if the region moves away from existing commitments to incineration and municipal solid waste (MSW) composting. Either way, Long Island could become the center for a pyrolysis-based recovery services industry serving global markets in municipal solid waste treatment and hazardous waste cleanup. 


\section{FINDINGS}

\section{Introduction}

Pyrolysis is a versatile technology that can convert many components of municipal solid waste (MSW), hazardous organic industrial wastes, such "special" wastes as tires and hospital refuse, and even old landfills into liquid or vaporous hydrocarbons and solid carbon (char). Waste volumes typically are reduced by $90 \%$, weights by $75 \%$. The hydrocarbon products can be recycled into new consumer goods or used to fuel transportation, generate electricity, or heat buildings. The solid carbon products have broad applications as coal substitutes, ingredients of manufactured goods, and filters to prevent or reduce hazardous waste pollution.

Pyrolysis breaks down materials to simpler molecules by heating them in an oxygen-free (or, according to looser definitions, reduced oxygen) environment. It is a reductive process, fundamentally different from incineration. Virtually any organic material can be pyrolyzed -- food, fiber, plastics, paper, rubber, crude oil, hazardous organic chemicals, and much of raw MSW itself. Because the process takes place in a sealed vessel, emissions are very low. Pyrolysis also lends itself to modular "just-in-time" systems that can be scaled and configured to match the quantities and kinds of waste to be processed.

Although it has been considered as a means of waste management since early in this century, recent improvements in the technology and changed circumstances make pyrolysis ripe for serious reconsideration now. During the past two decades many of the engineering problems that have inhibited its use have been overcome. Sophisticated pyrolysis processes for complex heterogeneous fuels have developed: (a) ways of decreasing oxygen and moisture content, corrosiveness, and frequency of repolymerization in storage of pyrolysis liquid products; (b) better understanding of complex simultaneous chemical reaction pathways as a function of temperature, heating rate, residence time, particle size, moisture level, and variety of hydrocarbon feedstock; (c) increased yield and quality of fuel products; and (d) new technologies for upgrading char as well as new environmental applications for it.

The advances in pyrolysis technology have been paralleled by progress in supporting technologies. Greater regularization of the sorting, grading, and quality control of materials for reclamation now promises more consistent pyrolytic feedstocks. Advances in controlling moisture and contamination of these stocks and in high- capacity feeding systems should increase efficiency and versatility. Several established engineering service companies, pyrolysis equipment sellers, and carbon processing equipment vendors now offer turnkey pyrolysis services with performance warranties.

Reflecting these circumstances, Japan and Europe (particulariy Germany) have markedly accelerated development of commercial-scale pyrolysis systems for treating municipal and non-hazardous industrial wastes. Since American companies have only begun to seize upon this technology in the last two years, the United States must play catch-up in order to tap the large incipient national and worldwide market for pyrolysis. NEWME can promote this effort by sponsoring further regional exploration and testing of the technology.

Suitably configured pyrolysis systems can play a very significant regional role in managing and recycling MSW and related wastes generated at national laboratories and other Department of Energy (DOE) facilities and minimizing hazardous and non-hazardous chemical wastes and bulk solid wastes generated by industries and DOE facilities, including wastes from site cleanup operations. Such systems can also provide cleaner fuel for transportation, heat or electricity generation; reduce reliance on nonrenewable fossil fuels; and help create a local recovery services industry to exploit 
the substantial national and worldwide commercial opportunities for pyrolysis and for allied environmental services and technologies. Each of these roles improves compliance with the Resource Conservation and Recovery Act (RCRA), the Clean Air Act Amendments (CAAA), the Superfund Amendments and Reauthorization Act (SARA), and other federal, state, and local regulations. And each role offers significant opportunities for collaboration among industry, universities, national laboratories, and state and local governments. Possible applications and practical considerations affecting their implementation are discussed below.

To gauge the potential of available pyrolysis technologies, I have studied their engineering performance, environmental effects, costs, product applications, and markets. The technologies were screened according to five criteria: technological readiness, commercial readiness, applicability to regional waste problems, applicability to DOE environmental restoration and waste management efforts, and global market potential with its regional economic benefits. Four American pyrolysis companies offer systems that best satisfy these criteria: Pan American Resources (Pleasanton, California); Conrad Industries/Tuttle Technologies (Charlotte, Michigan/ Chehalis, Washington); Hynol Corporation (New York, New York); and Entropic Technologies (East Lansing, Michigan).

These four systems differ in engineering design, scale of units, cost, and principal product. The Entropic Technology system is engineered to make a clean synthetic coal, the Hynol system produces methanol for use as a vehicle and utility fuel or fuel ingredient, the Conrad/Tuttle system produces a mixed alcohol (mostly methanol) that is blended with synthetic natural gas liquids to make a less polluting gasoline, and the Pan American Resources system generates electricity or pyrolytic liquids that can be converted to new plastics. The capabilities of each system are somewhat more flexible than this summary suggests, and each generates other products. (Table 1 presents a broad comparison. For technical descriptions of the four systems, see Appendix A. For a fuller account of their design, feedstocks, costs, prospective markets, and comparative strengths and weaknesses, see the comprehensive report.) All four systems appear to be cheaper and less polluting than non-pyrolytic alternatives in many applications. They also produce clean fuels and carbon for environmental cleanup, leaving minimal residual waste.

\section{Regional Applications}

\section{Municipal Solid Wastes}

Long Island's municipal solid wastes afford ample material for large-scale pyrolysis projects. Each year about 2.25 million tons of pyrolyzable materials not now nor soon likely to be recycled enter Long Island's MSW stream. One third $(750,000$ tons) is not currently managed acceptably by other means. This includes pyrolyzable components of municipal solid waste that is now landfilled; plastics that are too difficuit to recycle or too expensive to collect for recyciing; contaminated papers and plastics; rejects, residues, and bypass wastes from materials recovery facilities; unwanted, unrecyclable materials removed from MSW at incinerators or composting plants; wastes collected from certain commercial sectors; and such specialized wastes as auto shredder fluff (plastics and textiles). (See Table 2.) 
Table 1: Summary Comparison of MSW Pyrolysis Processes

\begin{tabular}{|c|c|c|c|c|}
\hline & Pan American & Entropic & Hynol & Conrad/Tuttle \\
\hline $\begin{array}{l}\text { Process } \\
\text { Conditions }\end{array}$ & $\begin{array}{l}650^{\circ} \mathrm{C} \text { for } 15 \text { minutes in a sealed } \\
\mathrm{O}_{2} \text {-free retort. }\end{array}$ & $\begin{array}{l}290^{\circ} \mathrm{C} \text { in an } \mathrm{O}_{2} \text {-free tube, heated } \\
\text { by friction from twin-screw feed. }\end{array}$ & $\begin{array}{l}\text { 1. Hydropyrolysis: } 800- \\
900^{\circ} \mathrm{C} \text { at } 30 \text { atm to yield char } \\
+\mathrm{CO}+\mathrm{CH}_{4}+\mathrm{N}_{2} \\
\text { 2. Steam Pyrolysis: } \mathrm{CO}, \mathrm{CH}_{40} \\
\mathrm{~N}_{2}+\text { steam at } 1000^{\circ} \mathrm{C} \text { and } 30 \\
\text { atm yields } \mathrm{CO}+\mathrm{H}_{2} \\
\text { 3. Methanol synthesis: } \mathrm{CO}+ \\
\mathrm{H}_{2} \text { at } 260^{\circ} \mathrm{C} \text { and } 30 \text { atm yields } \\
\text { methanol }\end{array}$ & $\begin{array}{l}540^{\circ} \mathrm{C} \text { in } \mathrm{O}_{2} \text {-free retort. } \\
\text { Second pyrolyzer powers } \\
\text { compressor. }\end{array}$ \\
\hline Products & $\begin{array}{l}\text { Char ( } 50 \% \text { carbon) }+ \text { low to } \\
\text { medium Btu gas. } 15 \% \text { of gases } \\
\text { used to drive pyrolysis. Rest can } \\
\text { be burned to make heat or } \\
\text { electricity, or liquefied and made } \\
\text { into heating oil, methyl tertiary } \\
\text { butyl ether (MTBE) or other } \\
\text { oxygenated fuel additives, or } \\
\text { plastics. }\end{array}$ & $\begin{array}{l}\text { Syncoal + gas. Gas burned to } \\
\text { produce steam to drive conveyor. } \\
\text { Syncoal used as low-sulfur utility } \\
\text { fuel, co-fired with coal. }\end{array}$ & $\begin{array}{l}\text { Char }+ \text { methanol. Methanol } \\
\text { can be used as liquid fuel co- } \\
\text { fired with oil in power plants, as } \\
\text { motor vehicle fuel, as an } \\
\text { ingredient in reformulated } \\
\text { gasoline, or as a basic industrial } \\
\text { chemical. }\end{array}$ & $\begin{array}{l}\text { Char + gases. Uncondensed } \\
\text { gas used to drive pyrolysis; } \\
\text { rest sent to alcohol synthesis } \\
\text { unit to produce mixture that is } \\
\text { mostly methanol. This alcohol } \\
\text { mix is blended with stripped } \\
\text { natural gas liquids (SNGLs) to } \\
\text { produce an alternative fuel } \\
\text { (synfuel) for automotive } \\
\text { engines. }\end{array}$ \\
\hline
\end{tabular}

Chars can be processed for use as a recyclable pollution adsorber, an ingredient in manufactured goods, or a component in a bulk secondary material.

All reactions are endothermic except for Hynol stap 1. Process conditions listed are for MSW feedstock with most metal and glass removed. The process temperatures and the composition of the char and of product gases or liquids can vary with feedstock. The above systems accept MSW (with most metals and glass removed before pyrolysis), carbonaceous MSW components (plastics, paper, food, textiles, yard waste, wood), and other wastes (including tires, automobile shredder residue, hospital wastes, materials from ofd landfills, hazardous and nonhazardous organic industrial chemicals and site cleanup wastes, and munitions wastes). Some of the above systems have special capabilities for certain of these feodstocks. 
Table 2: Targets of Opportunity for Pyrolysis in the Municipal Solid Waste Stream

\begin{tabular}{|c|c|}
\hline $\begin{array}{l}\text { Residential and commercial plastics not collected } \\
\text { or likely to be collected for recycling. }\end{array}$ & $\begin{array}{l}\text { Includes } 86 \% \text { of post-consumer plastic discards: polyethylene, } \\
\text { polypropylene, and polystyrene products not collected for recycling; } \\
\text { polyvinyl chloride; nylons and other polyamides; acrylonitrile } \\
\text { butadiene styrene and other engineering plastics; any food- } \\
\text { contaminated plastics; multi-resin and multi-material laminates and } \\
\text { composites; industrial and commercial packaging and production } \\
\text { scrap; household durable products. }\end{array}$ \\
\hline $\begin{array}{l}\text { Residential and commercial papers not collected } \\
\text { or likely to be collected for recycling. }\end{array}$ & Mostly lower grade, contaminated materials. \\
\hline $\begin{array}{l}\text { Pyrolyzable rejects, bypass wastes, and } \\
\text { processing residues from materials recovery } \\
\text { facilities. }\end{array}$ & $\begin{array}{l}\text { Approximately } 10 \% \text { of the materials delivered to municipal } \\
\text { recycling facilities (MRFs). }\end{array}$ \\
\hline $\begin{array}{l}\text { Materials that are collected in recycling } \\
\text { programs but never recycled. }\end{array}$ & $\begin{array}{l}\text { Because of production capacity bottlenecks or prohibitive costs, } \\
\text { these items are sorted at MRFs but never made into new products. }\end{array}$ \\
\hline $\begin{array}{l}\text { Unwanted "front-end" materials received from } \\
\text { MSW composting plants and incinerators. }\end{array}$ & Composition depends on facility's front-end sorting system. \\
\hline Food wastes. & Roughly $10 \%$ of MSW. \\
\hline Textiles. & $6 \%$ of MSW. \\
\hline \multicolumn{2}{|l|}{$\begin{array}{l}\text { Certain pyrolyzable commercially collected New } \\
\text { York City wastes brought to Long Island. }\end{array}$} \\
\hline Wood wastes and yard wastes. & Oniy when chipping or composting is not feasible. \\
\hline Automobile shredder fluff. & $\begin{array}{l}\text { Mostly plastics and textiles. The Town of Brookhaven currently } \\
\text { receives } 31,000 \text { tons/year at its landfill. }\end{array}$ \\
\hline Used oil. & When conventional re-refining systems are ineffective. \\
\hline $\begin{array}{l}\text { Raw MSW that now is either landfilled, or } \\
\text { shipped off-isiand, or exceeds the capacity of } \\
\text { available incinerators. }\end{array}$ & $\begin{array}{l}\text { The remaining bulk of raw MSW is designated for existing } \\
\text { incineration or planned MSW composting facilities on LI. }\end{array}$ \\
\hline $\begin{array}{l}\text { Pyrolyzable materials obtained from waste } \\
\text { exchanges. }\end{array}$ & There are at least two in NY State. \\
\hline
\end{tabular}

Note: does not include tires, landfill mining, hospital wastes, hazardous wastes, and certain industrial wastes; these are treated separately.

By concentrating on these wastes and others not strictly in the MSW stream, such as old tire dumps and closed landfills, pyrolysis would meet a clear-cut need, acting as an immediately useful complement to other waste management and recycling systems. This function is more valuable to integrated waste management than the mere label might suggest, since the quantity of wastes in question is quite large, and progress towards New York State's waste management milestones depends on finding ways to treat these heretofore ignored or intractable wastes productively. Besides plugging gaps in present waste management, in this role pyrolysis would buffer fluctuations in the recycling, incineration, composting, and landfill marketplaces.

Penetration into the second third of the 2.25 million tons of pyrolyzable MSW materials not destined for recycling would establish pyrolysis as one of the region's anchor waste management technologies. In this role, pyrolysis would be the technology of choice for much of the raw MSW 
now shipped off-Island, surplus recyclables engendered by adverse market conditions, and those currently incinerated materials that lower incinerator efficiency. Attainment of this role appears possible, but only with significant additional efforts, including coordination with regional cooperation mechanisms, carter negotiations, coordination with reclaimed specifications, and shared collection vehicles deployed with better logistics. Revenues from sales of pyrolysis products would also have to be high enough to keep tipping charges within the projected envelopes, and perhaps to subvent some competitive leeway in tipping charges if needed.

The final third of the 2.25 million tons would be available for pyrolysis only if there is a significant move away from the use of existing incineration capacity. Penetration into this part of the market would make pyrolysis the Island's principal or flagship waste management technology. Given the substantial incineration infrastructure already in place, this appears to be a long shot. (The import of recent Supreme Court rulings designating incinerator ash as potentially hazardous waste and overturning "flow control" arrangements cannot yet be gauged.)

How much material is now realistically available for pyrolysis? Some specialized waste streams, such as automobile shredder fluff, municipal recycling facility (MRF) rejects, and unwanted front-end materials from incinerators, should be fairly readily obtainable. Wastes shipped off-island by towns or private haulers are available for pyrolysis if tipping fees at the pyrolysis plant prove competitive with off-island disposal rates -- and the range of fees given out by the four pyrolysis companies singled out in this study suggest they would be. (Those tipping fees also are lower than current charges for incinerators and MSW composting plants on the Island.) Adjustments to residential, institutional and commercial collection protocols and transfer station and waste facility separation practices can enhance collection of plastics for pyrolysis. Towns that do not rely on incineration or seek to reduce their reliance, especially if the Supreme Court decision raises costs, are in the best position to entertain the pyrolysis alternative. Even in towns where contractual commitments to incinerators govern significant fractions of pyrolyzable wastes, incinerator operators may wish to divert pyrolyzable materials that reduce the efficiency of their plants.

Accommodating existing MSW infrastructures to pyrolysis calls for careful systems design that takes into account Long Island's variegated collection, processing, and disposition arrangements for wastes and recyclables while capitalizing on Long Island's regional advantages: short transportation distances, concentrated waste supplies, a well-articulated network of brokerage services and value-added processors, and ready access to marketing and distribution networks.

The full potential of pyrolysis for MSW can best be realized through regional multi-town arrangements. To avoid duplicating facilities and to realize economies of scale, several towns have begun to exchange wastes and recyclables and to share access to landfills, MRFs, and incinerators. Both the New York State Department of Environmental Conservation (NYS DEC) and the U. S. Environmental Protection Agency (U.S. EPA) encourage such efforts. The five major Suffolk County towns, working with the University at Stony Brook's Waste Management Institute, are exploring further cooperation, including possible formation of a regional waste management authority. Working with other area instrumentalities, such as the Long Island Recycling Cooperative, and comparable emerging regional agencies in Connecticut, Rhode Island, and Massachusetts, NEWME could help make the separation and preprocessing of pyrolyzable materials and the initiation of pyrolysis projects integral to a coherent Northeast regional approach to MSW management. 


\section{Industrial Wastes}

Many hazardous and non-hazardous liquid and solid wastes produced in large quantities by regional industry are pyrolyzable. These include solvents, coatings, treated wood, plastics, lubricants, agricultural chemicals, and hazardous organic chemicals derived from site remediation operations. Long Island electronics, aviation, plastics, utility, transportation, and metal finishing industries are large generators of pyrolyzable wastes.

Regional industry has a huge need for better, cheaper, and faster treatment, storage, disposal, and recycling technologies for its hazardous and non-hazardous wastes. Costs for managing these wastes have risen sharply in recent years. Far-reaching federal and New York State regulation has required companies to implement and monitor comprehensive waste prevention and minimization programs for industrial chemicals.

These circumstances should make pyrolysis increasingly attractive to industry. As an alternative to incineration, it offers lower costs without air emissions concerns or high-temperature process control challenges. Large waste generators may process materials in their own small on-site units, lowering transportation costs. On- or off-site pyrolytic treatment would sharply reduce the quantity of wastes requiring long-distance shipment (New York's only licensed hazardous waste landfill is near Buffalo). Other dividends may accrue if the use of pyrolysis helps reduce interstate movement of hazardous waste; pending legislation restricts or taxes such movement. The technology is also decidedly in step with industrial waste management's trend toward energy and material recovery, since it generates fuel, industrial hydrocarbons, and adsorbent carbon.

Pyrolysis also can be integrated with industrial waste exchanges. New York State has two of these clearinghouses for trade in materials for reuse and recycling as chemical agents or feedstocks. Among pyrolyzable wastes traded are solvents, other organic chemicals, oil and wax, plastic and rubber, textiles and leather, wood and paper, paints and coatings, unwanted hospital linens, diskettes, paints, and printed circuit board scrap. A pyrolysis system linked to the Northeast Industrial Waste Exchange could process materials that find no outlet. It may be possible to extend this network to some construction and demolition debris. As part of an integrated recovery services industry, industrial pyrolysis on Long Island could spin off related entrepreneurial activity in monitoring, separation, and processing technologies.

\section{Tires}

The lackluster economic environment for scrap tire recycling and incineration creates opportunities for pyrolysis. Competitive prospects for mechanical recycling of scrap tires have become fair to poor in most applications. Limited demand, high processing costs, and low crude oil prices have restricted the use of reclaimed crumb rubber for consumer products such as floor mats. Although highway applications may be more promising in the long term, concerns about environmental and health impacts, long-term performance, lack of engineering specifications, and high costs have recently led Congress to prohibit use of federal funds to implement or enforce its 1991 mandate to increase use of rubberized asphalt. Tire incineration to generate energy has also fallen on hard times; for example, the huge Oxford Energy Company operation in Modesto, California filed for bankruptcy in 1993.

Newly discarded tires do not call for NEWME attention because, in this region, existing commercial networks capture them efficiently for export, incineration, or in some instances, pyrolysis. On the other hand, stockpiled tires in the Northeast are excellent candidates for NEWME 
attention. EPA estimates that U.S. tire stockpiles hold 2 to 3 billion tires. The significant market potential for pyrolysis of stockpiled tires in the Northeast is enhanced by the generic beneficial use determination (BUD) the NYS DEC has accorded tire pyrolysis. An immediate opportunity is presented by a stockpile of some two million tires (15,000 tons) in Kings Park on the North Shore of Long Island. This privately owned, illegally accumulated fire hazard has been a source of vexation to government agencies and the public for years. Although the Town of Smithtown has been reviewing four solicited non-pyrolysis proposals, no decision is expected soon and officials say they will give due consideration to NEWME-sponsored pyrolysis proposals. Eliminating so rankling a nuisance could showcase the value of the technology.

\section{Hospital Wastes}

Long Island hospitals generate roughly 160 tons of wastes per day, a high fraction of which is paper and plastic suitable for pyrolysis. Costs of current methods of disposal (incineration, sterilization, and landfilling) have been rising steeply. Each of the four companies whose pyrolysis systems qualify for further consideration by NEWME covets this market, for which closed-container systems integrated from point of generation through transportation to shredding and pyrolysis are particularly attractive.

\section{Landfill Mining}

Successful landfill mining could eliminate unsightly, malodorous landfills or greatly extend their service lives, deferring or avoiding high landfill closure and post-closure costs to towns. Three of the qualifying pyrolysis companies are seeking such mining opportunities, and two of them (Pan American and Entropic) appear to have a higher tolerance than incinerators or other pyrolysis systems for the inert materials that vex attempts to recover useful materials from old landfills.

Assistance for landfill mining projects is available from the New York State Energy Research and Development Authority. Since engineering development for pyrolysis of old landfills has much in common with that for pyrolysis of contaminated soils, DOE may also have an interest in fostering this application for eventual use on its remediation sites. Brookhaven National Laboratory's own landfill might be the site of a demonstration project to refine the technology for these related applications.

\section{Energy Applications}

The products of pyrolysis can be used as fuel for electricity generation, industrial process heating, and transportation. Commercial use of cogenerated heat and/or steam le.g., in greenhouses) may be an added benefit. Depending on the system chosen, the primary fuel from pyrolysis would be electricity (Pan American Resources), syncoal (Entropic), methanol or methanol derivatives (Hynol), or an alcohol mix blended with stripped natural gas liquids to make a low-octane engine fuel (Conrad/Tuttle). Other energy products are available with different system configurations. There are defined utility and transportation markets for these products.

Special opportunities exist on Long Island, where, according to Peter Quinn, energy chairman of the Long Island Environmental and Economic Roundtable, high energy costs have been the primary factor in the loss of more than 110,000 jobs in the last four years. The 1993 Strategic Economic Development Plan drawn up by the Long Island Regional Planning Board calls for measures to reduce independent power producers' rates, and for increased natural gas imports to 
the Island. Such imports would be required for a 145-megawatt natural-gas-fired Long Island Lighting Company (LILCO) plant under construction in Holtsville. The New York Power Authority is also advocating construction of a natural-gas fired 340-megawatt electricity generation plant at Pilgrim State Hospital in Islip. Pyrolysis could provide a local source for some of this fuel, perhaps in conjunction with landfill gas recovery operations.

Long Island is also a Clean Air Act noncompliance area in which oxygenated automotive fuel is required. Methanol and oxygenated fuels such as methyl tertiary butyl ether (MTBE) are primary markets for the Hynol, Conrad/Tuttle, and possibly the Pan American Resources systems. The end-user prices per gallon quoted by these companies are competitive with regional gasoline prices. Tax credits being considered by Congress to encourage development and use of such fuels may enhance the economic outlook for these pyrolysis systems. It may also be possible to leverage support through federal fleet conversion programs, since the government will buy tens of thousands of alternative-fuel vehicles $(35,000$ annually by 1997$)$ under an interagency program chaired by an Assistant Secretary of DOE. The New York State Energy Research and Development Authority also conducts an Alternative Fuels for Vehicles program, and DOE and U.S. EPA are developing other programs in this area, further expanding opportunities to use pyrolytic products in fuelling federal and state fleets.

Factors Affecting Regional Adoption:

Regulation, Siting, Official and Public Attitudes

The New York State Department of Environmental Conservation has not yet formally determined whether towns may count tires, plastics, or other wastes pyrolyzed for electricity or fuel recovery towards satisfaction of state recycling goals, although the State does include these wastes in its own calculations of progress towards these goals. Nor has NYS DEC addressed the possibility of allowing recycling goal credits for wastes that are pyrolyzed and then turned into new plastics or other consumer products. Favorable regulatory changes in Washington, Ontario, and Michigan, distinguishing pyrolysis from incineration and grouping one low-temperature pyrolytic process with conventional recycling, offer encouraging precedents.

NYS DEC officials maintain that the agency hopes to encourage development of pyrolysis so as to enable Long Island recycling programs to meet state management goals by processing difficult waste stream components beyond the reach of current measures. They also have said they consider the technology's energy, materials recovery, and poliution prevention dividends to be substantial. The NYS DEC permits pyrolysis of hazardous organic materials under regulations covering performance standards for boilers and industrial furnaces.

Some town officials see major waste management benefits from pyrolysis; others express skepticism. Apparently unfamiliar with recent technological advances, skeptics recall engineering difficulties encountered in previous decades, or cite potential citizen opposition to anything new. Such opposition may come not from environmentalists, many of whom support pyrolysis, but from neighborhood groups fearing potential hazards of facilities sited in their areas. While standard industrial safety technology makes the chances for any accident very remote, and lower than they would be at many extant facilities, including utilities, storage tanks, and incinerators, it may be advisable for NEWME to sponsor a formal risk analysis.

Pyrolysis will gain public acceptance to the extent that: (1) it is perceived to be a cleaner alternative to burning, without the incinerator's telltale chimneys; (2) it is seen as a type of biomass/biofuel processes and as a "win/win" technology for making clean air fuels; (3) it demonstrates its effectiveness by treating visible or difficult waste problems; and, (4) it is cheaper 
than recycling, incineration, MSW composting, or off-Island shipping. Only the last of these waste options appears to have any chance of upsetting the competitive economics of pyrolysis, and then only if the price of off-Island landfilling drops substantially. Such a price cut, however, would also weaken the competitive position of the other waste management options; and regulatory and technological factors appear more likely to renew the trend towards rising disposal costs, especially as recycling supply and demand bottlenecks are cleared. Siting of pyrolysis facilities may also be more acceptable as part of a "land recycling" package in which the plant is used to clean up one of Long Island's polluted industrial properties; or as a source of electricity to run recycled plastics lumber plants and other recycling/reclamation facilities, thereby retaining enterprises now being driven from the region by high energy costs.

\section{Wider Applications}

\section{DOE and Other Federal Site Cleanup}

Approximately 4,000 contaminated Department of Energy sites require remediation and/or restoration. The predominant contaminants are hazardous organic compounds: fuel hydrocarbons (toluene, benzene, and xylene); chlorinated hydrocarbons (trichloroethylene); ketones (acetone); polychlorinated biphenols (PCBs); pesticides; and organic acids. All of BNL's four sites are contaminated by chlorinated hydrocarbons, three of them by fuel hydrocarbons. PCB-contaminated oil is aiso present. Similar hazardous organic chemicals are found at most of the 750 Superfund sites on the National Priorities List (NPL) established by the Environmental Protection Agency. Many DOE sites are also on this list. Four to eight hundred new sites are expected to be added to the NPL by the end of this decade. Fuel hydrocarbons and other hazardous organics also are found at many of the 295,000 underground storage tank sites requiring remediation.

Many of these contaminants can be processed directly by pyrolysis. Others would yield pyrolyzable wastes after primary treatment by stripping of solvents and fuels in-situ, bioremediation, volatile organic carbon (VOC) recovery with mist-scrubbers or by membrane vapor separation, hydrocyclone systems, ultrasonic metal separation, electrokinetic migration, soil washing, or vapor extraction. Pyrolysis could destroy many of these remediation products at lower costs and temperatures than incineration. Since many of the remediation technologies have been developed by $D O E$, there are attractive in-house capabilities to develop integrated approaches using pyrolysis as the final step in the destruction of hazardous organics.

While the greatest opportunities for such projects appear to be at DOE and Superfund sites elsewhere, important Long Isiand applications could be considered. Besides BNL, there are twenty-four Superfund sites on the Island, only three of which have been completely cleaned up; fuil-scaie cleanups are underway at two others. There may be opportunities for pyrolysis at Ruco Polymer, Liberty Industrial, Pasley Solvents, Anchor Chemicals, Kenmarks Textiles, Action Anodizing, Mattiace Petrochemicals, and other sites. There also are 115 state Superfund sites on Long Island.

In principle, pyrolysis is a suitable treatment for many mixed (hazardous and radioactive) wastes at DOE sites. However, this would require dedicated pyrolysis units that would eventually have to be disposed of as low-level radioactive waste.

Mandated waste minimization programs for ongoing DOE and Department of Defense (DOD) operations may also prove fertile ground for pyrolysis. DOE policy stresses aggressive pollution prevention goals, including a $50 \%$ reduction in emission of priority chemicals in the Toxic Release Inventory (TRI) by the end of 1995 at some DOE sites, and a 33.3\% cut at others. DOE also has 
undertaken to comply with the 1990 CAAA, which call for pronounced efforts to reduce VOC emissions. These policies will change DOE waste streams in many ways, creating opportunities for pyrolysis of hazardous organic chemicals.

For remediation and/or ongoing waste management, pyrolysis units could be sited at present or former major federal installations. Smaller transportable field units may be attractive in other situations. A few mobile units could "circuit-ride" as needed among DOE remediation or current operations sites. A fixed or mobile facility might be sited at a contaminated industrial site in exchange for remediating the property.

Clean activated or semi-activated char from pyrolysis plants could also contribute to DOE remediation efforts. After being purged of its VOCs and other hazardous organics by pyrolysis, saturated filter carbon could be reused. Hazardous organic gases that survive pyrolysis could be destroyed by high-temperature flaring. Char containing heavy metals could be placed in a hazardous waste landfill when metal recovery is not desirable or feasible.

Pyrolysis may help reduce the runaway costs of federal environmental restoration and waste management operations, with added savings if DOE cleanup and operational wastes are pyrolyzed in the same plants with industrial hazardous and non-hazardous wastes. Business opportunities are substantial. From $\$ 3.4$ billion in 1992, the hazardous waste cleanup market in the United States is expected to triple to $\$ 11.2$ billion in $1999 .^{1}$

\section{National and International Opportunities for Pyrolysis and Related Environmental Technologies}

Opportunities similar to those on Long Island for large-scale pyrolytic processing of MSW, plastics, tires, and industrial, hospital, and old landfill wastes are available in most other densely populated parts of the United States. Some groups argue that it should be considered a form of recycling with the same priority as conventional mechanical recycling. A different approach is taken by a proposed new National Recycling Coalition hierarchy that rates pyrolysis "for recovery of materials and fuel products" below source reduction, reuse, conventional recycling, and composting. Nonetheless, it still ranks above the predominant modes of solid waste treatment, incineration (with or without energy recovery) and landfilling. Very large quantities of wastes remain available for pyrolysis under such guidelines. Pyrolysis is also the backup treatment of choice for each of the first four options when mechanical recycling markets dry up for a particular material, when material is too contaminated for recycling, when food wastes interfere with composting, when commingled plastics and/or other organics are not economically or technologically separable, or when materials and up as MRF residue or bypass.

Niche markets such as plastics-to-plastics, old tire piles, automobile shredder fluff, hospital wastes, and industrial non-hazardous wastes are attractive opening wedges in commercializing pyrolysis because of better feedstock quality control, high tipping fees for alternative dispositions, and stiffer regulatory requirements. States that credit pyrolyzed wastes as a form of recycling or recovery may offer tax or other financial incentives. Markets for resultant electricity or utility and transportation fuels will reflect the predominant regional energy sources and prices, rail and truck access, distribution markets, and Clean Air Act status and tax advantages.

1 Frost and Sullivan Market Intelligence. Site Cleanup Under Superfund, DOD, and DOE Markets. Mountain View, CA. 1993. 
National opportunities appear very strong in hazardous waste remediation at DOE and Superfund sites, and in waste minimization and pollution prevention programs at operating private industrial and federal laboratory facilities. The driving forces are regulation and lower costs. Pyrolysis is one of several emerging techniques that promise to lower the skyrocketing costs associated with management of hazardous wastes. The allied remediation and pollution prevention applications of carbon products to filter and sequester hazardous wastes also could command high prices nationally.

These are the core national commercial opportunities. If pyrolysis gains a market foothold, considerable commercial spin-offs would follow to improve integration with emerging waste separation technologies (e.g., for VOC separation from industrial or cleanup waste streams, or for plastics separation from MSW), and with monitoring and sensing technologies. Commercial opportunities to incorporate low-quality char in secondary materials and to develop new environmental applications for high-quality char also appear viable.

Most national opportunities are also major global opportunities -- particularly pyrolysis of hazardous wastes, plastics, and MSW, and the development of associated separation and monitoring technologies. There also would be opportunities for joint projects between DOE and corresponding governmental agencies around the world, and with international agencies. For example, pyrolysis companies are interested in using pyrolysis to destroy NATO and Warsaw Pact wastes, including chemical warfare agents. The potential market for small modular or mobile units appears particularly promising.

The determined Japanese and German efforts to commercialize pyrolysis technology should make clear the need for an American entry into this arena. Long Island's superb high-technology work force and technology infrastructure make the region a logical launching pad for such an effort. The major global opportunities for pyrolysis of hazardous and non-hazardous wastes are in Western Europe, Eastern Europe, the former Soviet nations, India, China, Taiwan, and Korea. All of these regions have begun to mount substantial efforts to repair old pollution and manage existing wastes properly. The language skills available in the Long Island/New York City area are a distinct advantage in penetrating these markets.

A successful nationally and globally oriented regional recovery services industry built around pyrolysis would obviously benefit the Long Island economy -- in manufacturing, servicing, and selling processing, monitoring, and separation equipment, and in providing analytical, research, and engineering services. The scale of the national and global opportunities may be gauged by the fact that the worldwide "green technology" market in 1993 was $\$ 250$ billion and is projected to be $\$ 600$ billion by $2000 .^{2}$ The flexibility of pyrolysis in turning many waste liabilities into keystone industrial and energy assets makes it attractive to countries seeking resource self-sufficiency and clean environments in the face of growing populations. Pyrolysis technology has matured in recent years, and is well-positioned to hold its own in the global "green technology" market. 


\section{RECOMMENDATIONS}

\section{NEWME}

\section{MSW and Specialized Wastes}

NEWME should promote construction of a commercial-scale (50 or more tons per day) pyrolysis facility to process targeted parts of Long Island's MSW. All four companies have declared strong interest in developing a facility on Long Island, and can submit proposals promptly. Each is willing to commit substantial money, equipment, and technical expertise to achieve a market breakthrough in this region. NEWME should sponsor discussions between them and appropriate local, state, and federal officials, acting as neutral broker to facilitate the building and operation of such a plant. Discussions also could be coordinated with Stony Brook's Waste Management Institute, especially if plans of the five largest Suffolk County towns to explore regional waste management programs bear fruit.

These discussions would cover facility size and siting, potentially available wastes lincluding materials sent from MRFs or incinerators), ownership and operating responsibility, tipping fees and product revenue sharing, cost-sharing of separation equipment, and regulatory determinations. Other parties, such as carters, utilities, and petrochemical marketers, should be brought in when appropriate.

Proposals should be invited to target initially one or more specialized waste streams now inadequately managed and readily pyrolyzable, such as the Kings Park tire stockpile, automobile shredder fluff, plastics not captured by recycling programs, pyrolyzable MRF rejects and residues, institutional, restaurant, and supermarket food wastes, and textiles, to be followed in a later stage by processing of available raw MSW. NEWME should select the best of the four company proposals, giving considerable weight to the advice of the town governments and other interested parties.

While proposals are being solicited and evaluated, efforts should begin to locate pyrolyzable wastes obtainable from specific generators (including BNL) or stockpilers, including suitable bulk industrial and commercial scrap, all of which should conform to the strategy of complementing the existing waste management infrastructure. At the same time, potential sites for the facility -- at $B N L$, idle industrial properties slated for cleanup, active industrial sites and industrial parks, and even locations in New Jersey -- should be investigated. University, national laboratory, and business partners would be engaged for supporting technical and regulatory assessment projects, as articulated in subsequent recommendations and in the comprehensive version of this report.

\section{Site Reclamation}

NEWME should foster construction of a smaller fixed or mobile facility for processing wastes from cleanup of contaminated DOE sites and from active DOE facilities. BNL should develop an action plan for the use of such units in DOE and other federal cleanup applications. NEWME should host discussions between the four companies and BNL/DOE to identify equipment and engineering development needs and assess costs for pyrolysis of federal site remediation and DOE processing wastes. This process should lead to a contract between DOE and the company with the best plan.

Simultaneously, BNL should develop a DOE-wide action plan for using pyrolysis in these federal applications. BNL and university partners would (a) identify and rank DOE sites and materials for their suitability to pyrolysis as a primary or secondary treatment; (b) quantify the waste streams that would be treated and generated, assessing ways to minimize costs, wastes, and risks; 
(c) complete the engineering development of mobile units, front-end separation systems, and field sensing and monitoring systems; and; (d) identify opportunities to use and recycle carbon char in DOE cleanup operations. BNL's User Facility for Environmental Pathway Modeling of DOE environmental restoration sites could be used to assess pyrolysis options, and all these activities should be coordinated with BNL and other DOE development of waste stabilization and bioremediation technologies to maximize opportunities for synergisms in treating contaminated sites as total systems. The action plan should lead to the construction, field demonstration, and assessment of a pyrolysis unit as soon as is practicable.

To assist these efforts, and to develop pyrolysis applications that minimize wastes covered by TRI, Clean Air Act Amendments, and other regulations, NEWME/LIRI should promote collaborations with regional industries. If it is approved for ARPA funding, the "Environmentally Benign Manufacturing Technologies" program proposed by a consortium of area defense and consumer electronic firms and SUNY/Stony Brook would be a logical place to start.

\section{Recovery Services Industry}

NEWME's efforts should be directed to establishing on Long Island an integrated recovery services industry marketing pyrolysis applications and ancillary systems and services to the nation and the world.

Long Island's development of pyrolysis should be conceived as part of an integrated recovery services industry, producing useful energy and materials and sequestering hazardous materials from a broad range of municipal, industrial, and clean-up wastes. Such an industry would spin off related entrepreneurial activity in monitoring, separation, and processing technologies, and in environmental consulting and assessment services. To assist this emerging industry, NEWME should help arrange for local, national, and global business opportunities, acting as a conduit to and from such large potential markets as the former Soviet Union, Eastern and Western Europe, Turkey, China, and Southeast Asia.

In the longer term, research, manufacturing, environmental monitoring, and consulting opportunities may arise in connection with the alternative fuel applications of the products of pyrolysis. Several federal agencies, the New York Power Authority, New York State Energy Research and Development Authority, New York State Department of Transportation, New York State Department of Environmental Conservation, Long Island Lighting Company, Long Island Railroad, heating oil companies, and various trade groups could develop such environmentally beneficial uses of hydrocarbon products as alternative-fuel transportation development, energy storage for load management, and cogeneration.

For projects 1, 2, and 3, NEWME should seek matching funds from industry, government, and trade organizations, promote university and national laboratory research and assessment, and spotlight international market opportunities for regional manufacturing and environmental firms.

\section{Brookhaven National Laboratory and its Academic and Industrial Partners}

In addition to its role in formulating a DOE action plan (p. 18), BNL is equipped to take the lead in: research, development, and demonstration projects addressing unresolved technical issues pertaining to the pyrolysis systems; assessment and performance studies for DOE and DOD wastes; and regulatory and environmental impact studies bearing on both these areas. These projects could involve other DOE labs and other federal and state agencies, as well as area universities and industries and pyrolysis systems manufacturers /who are prepared to commit considerable resources 
to joint projects). Projects should be highly leveraged, taking full advantage of CRADAs and other instrumentalities to obtain private and government funding.

Specifically, BNL's resources could best be deployed on these fronts:

1. conducting tests to determine physical and chemical composition of available MSW and hazardous waste feedstocks, including those associated with DOE site remediation;

2. developing advanced thermochemical computer modeling and sophisticated continuous process and emissions monitoring instrumentation;

3. conducting tests and building a database on the effects of varying feedstock composition and operating temperatures on physical and chemical composition of char and product gases and condensates, and adiabatic flame temperature and flue stack emissions (test-scale equipment is available from some of the pyrolysis companies);

4. engineering development and physical-chemical testing to mate recently developed methods of upgrading char with pyrolysis units processing various feedstocks;

5. improving separation of product gas streams so as to maximize product uniformity and energy value and minimize impurities;

6. improving sorting and size fractionation technologies so as to maximize the range and efficiency of feedstock processing;

7. developing char product applications in DOE cleanups, manufacturing processes, and secondary materials;

8. studies in connection with the DOE-wide action plan mentioned on page 18;

9. development of transportable field units for DOE cleanups;

10. assessing the reduction in pollution and wastes, the health and safety risks, and the regulatory requirements associated with pyrolysis systems, including their environmental cleanup and alternative fuels applications. 


\section{APPENDIX}

\section{Pan American Resources}

The Pan American Resources (PAR) "Destructive Distillation" pyrolysis system accepts raw MSW feedstock (with glass and metals removed by 'front-end' separation devices), and all types of organic solid wastes individually or in combination (plastic, paper, wood, yard wastes, food). The system is also designed to process old landfills, hospital wastes, and tires, and hazardous organic wastes, including ammunition wastes. The company has some eight years of cumulative operating experience with various feedstocks.

Feedstock is shredded into $1^{\prime \prime}$ pieces and dried at $170^{\circ} \mathrm{C}--$ for MSW, this reduces moisture content from $25 \%$ to under $10 \%$-- and fed continuously through an air seal into an oxygen-free retort. Residence time in the $650 \circ$ retort is 15 minutes. Product char exits continuously through an air seal. Product gases vary from a low- to a medium-Btu fuel, depending on feedstock, that can be enriched with methane, if need be, to bring the Btu value to desired levels. Fifteen per cent of the product gases are burned under the retort to drive the (endothermic) pyrolytic reaction.

One ton of MSW yields roughly 928 pounds of product gas, 160 pounds of carbon char and 260 pounds of inert materials (glass, non-ferrous metals) incorporated in the char. Upgrading options are discussed below.

One ton of organic solid waste feedstock yields about 60 gallons fuel oil. The yield from a 250 ton/day Destructive Distillation plant has been estimated to result in a net savings of 100,000 barrels of oil annually. With catalysis, the oil can be synthesized into $\mathrm{C7}$ or $\mathrm{C} 8$ oxygenated fuel additives, such as MTBE, that comply with provisions of the Clean Air Act Amendments applicable to the Long Island region.

Several options are available for the product gas mixture. (a) In what is PAR's basic configuration, product gases are burned directly in a steam boiler on-site to provide energy for the facility and to make electricity for sale to local utilities at PURPA prices. Steam and/or cogenerated waste heat could be used by a collocated or adjacent industrial park or institution. Storage of pyrolytic gases or liquids is not required. (b) It also is possible to transport the gases to a utility or industrial cogeneration plant for electricity generation there. Product gases instead can be liquefied and then (c) catalytically synthesized into MTBE or other C7 or C8 oxygenated fuels, or (d) sent to a refinery for conversion to heating oil, petroleum, plastics, or other petroleum products. Finally, when certain hazardous waste feedstocks are used, (e) gases could be flared at $1,650^{\circ} \mathrm{C}$ to dissociate any dioxins, furans, $\mathrm{PCB}^{\prime} \mathrm{s}$, or other hazardous organic materials present in the original feedstock that may have survived pyrolysis.

The char from MSW feedstock is $50 \%$ carbon. The volume of char is $3 \%$ of that of the original, unseparated MSW. This volume reduction is significantly greater than that from incineration. By weight, char averages $15 \%$ of the organic material in MSW, and $21 \%$ of the original MSW before metals and glass separation.

The char can be treated. Char is $3 \%$ (by weight) ash for MSW feedstock, $6 \%-11 \%$ ash for tire feedstock. Ash is removable with air classification and by recently developed upgrading technologies, including Innovative Conservation technologies identified by DOE, such as a degreasing and acid leaching process that lowers ash content to $0.5 \%$, yielding a high-value activated carbon product. 
The carbon in the char is either semi-activated or fully activated, depending on feedstock and processing regime. High-pressure steam can fully activate any partially activated carbon. Activated char is a marketable filter/absorbent that removes pollution from liquid/gas waste streams in several industries, and from oil spill cleanup wastes. Following such applications, the then VOC-laden activated carbon can be decontaminated and regenerated by running it through the destructive distillator again.

Activated carbon also has uses in making rubber, paints, and other materials. It may be possible to use new processes, such as the Enviro-Clean process, recommended for development by the DOE Innovative Conservation technologies program, to recycle valuable heavy metals that may be present in the char (whether from a contaminated original feedstock or from environmental remediation operations). The process uses acid regenerants to remove heavy metals absorbed onto granular- activated carbon, after which the metals are recovered electrolytically from the solution. Alternatively, any such heavily contaminated chars can be sent to a hazardous materials landfill.

PAR has developed systems and equipment for pyrolysis of old landfills lusing high-speed carbide shredders that dry and grind simultaneously), medical wastes (with sealed shredding and processing, and sodium hypochlorite sterilization).

With the ram injection system that is standard equipment on the PAR system, up to $20 \%$ tires (by weight) can be mixed with MSW or other feedstock. Higher percentages are feasible, but require modifications to the feed system. Steel would be recovered for recycling.

The PAR system is designed to decompose liquid and solid hazardous organic process wastes from industry and from site remediation activities. These include solvents, chlorinated hydrocarbons, VOC's, and treated railroad ties and CCA lumber, and printers' inks. Certain non-hazardous industrial wastes also may be treated. PAR states that PAR can process most hazardous organic materials along with MSW or separately, in either case with no modifications in equipment.

Sewage sludge and some industrial sludges also are processable. These materials are beyond the scope of this report.

A 1985 study of a commercial-scale PAR demonstration plant that operated under a DOE grant concluded that

the results of the final testing and evaluation ... indicates [sic] that the invention has the ability to provide substantial energy savings in an environmentally safe manner, utilizing municipal solid waste as its sole source of fuel. The technology, dry distilation, should be able to convert a wide variety of potentially hazardous waste products into useable energy without polluting the atmosphere. These include garbage, pharmaceutical waste, printers' inks, paper, plastics, railroad ties, barnyard waste, oil, paint, grease, rubber, solvents, agricultural waste, and other organic material. ${ }^{3}$

The DOE study measured airborne gaseous and particulate emissions from the 50 ton/day PAR demonstration plant. Both controlled and uncontrolled emissions were found to be much

3 Pfeffer, R., Tardos, G., and LaCava, A. 1985. Evaluation and Test Program of a 50-Tan Per Day "Waste Distillator." U.S. DOE Report No. DOE/CE/15126-T4-DE85-013429. Washington, DC. June 1985. 
lower, for virtually all pollutants measured, than comparable emissions from a California mass-burn incinerator and a Canadian two-stage starved air incinerator. Additional net pollution reductions would accrue from the use of pyrolysis-derived products such as oxygenated gasolines, electricity, or new plastics that substitute for conventional petrochemical-derived products, and such as activated char in environmental cleanup and process pollution control applications.

The DOE study also found that any heavy metals present in the feedstock are encapsulated in the char in a way that strongly inhibits leaching of the metals, should the char be landfilled. No polychlorinated dibenzodioxins or dibenzofurans were detected in the char or the other solid or gaseous product streams in the DOE tests.

Fifty and one hundred ton/day units are used la 50 ton/day unit processing MSW could serve a "wasteshed" of 125,000 people). Capital costs for a turnkey 100 ton/day plant (pyrolysis unit, front-end separation and shredding equipment, steam and electricity generation equipment, etc.) on Long Island are estimated to be $\$ 13.5$ million or less (a 50 ton/day facility could run $\$ 9$ $\$ 10$ million). An available 100 ton/day pyrolysis unit costs $\$ 400,000$ to $\$ 500,000$; a new one would cost upwards of $\$ 1$ million. It may be possible to lower or parry full system capital and operating costs by arranging to use existing separation, shredding, and power generation equipment on Long Island. Two to three acres would suffice, but three to five acres would be desirable. A crew of 28 (total, not per-shift) would operate the 100-ton plant on a 24-hour/day, 7-day/week basis.

PAR states that a tipping fee of at most $\$ 60$ ton, averaged over all feedstocks, would ensure profitability. Other revenues could be shared by PAR and towns. A 100 ton/day facility selling electricity for 6 cents/kwh (a low price for Long Island) would yield a revenue stream of from $\$ 15 /$ ton to $\$ 60 /$ ton, depending on feedstock, for a minimum income of $\$ 540,000 /$ year. At $\$ 10$ per 1,000 pounds, steam sales could return $\$ 1.8$ million annually. At 160 pounds of carbon char per ton of MSW, current market prices (70 cents/pound) would return $\$ 112 /$ ton of MSW. (Another source contacted quoted current prices for high-grade virgin activated carbon as running from $\$ 0.75$ to $\$ 1.50$ per pound. The many grading subclassifications make comparisons elusive. Tipping fees would make up the difference.

LILCO or other utility participation may be worth discussing. A 250 ton/day MSW pyrolysis plant would generate between 2.5 and 10 megawatts of electricity.

Potential revenue varies with feedstock. Hazardous wastes would command very high fees. To take another example, using standard tire properties, processing 20,000 tires/hour at $650^{\circ} \mathrm{C}$ yields 655 pounds of carbon. At $\$ 1 /$ pound for the particular grade of high-grade carbon that can be produced, revenue becomes $\$ 655 /$ hour. Markets for this material vary strongly with its quality, and it is unclear that this revenue is realistic given the effectiveness and costs of current upgrading techniques. However, as noted, economics for the PAR system depend on tipping fees and electricity or other energy product sales. Any char-related revenue is regarded as an extra dividend.

Prospects for revenue from sales of liquified pyrolysis products (for fuel or plastics recycling applications) are expected to be similar to those for the liquid products of the Conrad/Tuttle Technologies system.

A 4-ton/day PAR demonstration unit could be made available to SUNY/Stony Brook and/or Brookhaven National Laboratory for environmental engineering studies Igas chromatography, continuous emissions monitoring, materials studies, modeling the relationship between MSW feedstock variations and the makeup of product gases). PAR also is interested in developing ways 
to use char in concrete construction blocks, sound barrier walls and other bulk infrastructure applications, and containment barriers at contaminated waste sites.

\section{Entropic Technologies}

The Entropic technology produces a synthetic coal by pyrolysis of organic components of shredded MSW. Pyrolysis occurs in a small, simple tube at very low temperatures generated entirely by friction from mixing augers that act as a kind of waste "meat grinder."

A series of shredding, separation, and size fractionation steps first removes metals, glass, and building materials from MSW and converts the remainder into a refuse-derived fuel (RDF) of sufficiently uniform consistency. Next, a twin-screw conveyor continuously moves 8 tons of RDF per hour per screw through the pyrolysis reactor (called the "carbonizer" in company literature). The reactor is simply a 12-inch diameter cylinder 25 feet long. Friction from the screws' mixing action heats the feedstock to $290^{\circ} \mathrm{C}$. No other heat source is used. The RDF feedstock contains varying proportions and grades of plastic, paper, food scraps, cardboard, fabrics and other soft items, and fine inorganic solids. This feedstock also helps lubricate extruder surfaces.

Off-gases (with a condensible oil) are burned on-site to produce energy to make the steam that drives the conveyor. Gases are removed as material travels down the screw, resulting in an odorless, greaseless syncoal. Burning of off-gases at $1,650^{\circ} \mathrm{C}$ destroys all hazardous organic compounds that may have been present in the original MSW. No detectable levels of hazardous organic substances have been found in the condensible oil. Acid gases and particulates are removed from flue gases by means of a dry sodium sesquicarbonate scrubber and a baghouse.

One ton of unprocessed MSW yields 1,513 pounds of RDF, which is pyrolyzed into 700 pounds of volatile gases and 832 pounds of syncoal. The lower the temperature of pyrolysis, the greater the proportion of char byproduct. In the Entropic system, the design goal of maximizing syncoal production dovetails with the low temperatures possible from the mechanical energy of mixing alone. The pyrolysis tube is oxygen-free except for remanent oxygen in small voids in the feedstock.

On average, of the 487 pounds (of the ton of incoming raw MSW) that is not made into RDF, 275 pounds are unprocessables that are landfilled, and 212 pounds are recyclables recovered in the separation steps.

The heating value of the syncoal is 9,500 or more Btu/lb $170 \%$ of the heating value of the RDF). The syncoai has passed EPA's EP Toxicity test both as uncombusted fuel and as combusted ash; the combusted ash has passed the TCLP Analysis test. In these tests, the species concentration for virtually every element was very substantially below regulatory limits. Other EPA-approved tests found no detectable quantities of potentially carcinogenic chemicais of concern, such as dioxins, trichloroethylene, and other volatile organic compounds, among the one hundred or so compounds covered by these tests. Syncoal itself is formed at temperatures too low for dioxin formation, and burns at temperatures $11,370^{\circ} \mathrm{C}$ or higher) that destroy hydrocarbon precursors of dioxins.

The syncoal is a low-sulfur (under $0.25 \%$ ) coal chemically similar to Western sub-bituminous coal, but with virtually no moisture and with ash content similar to that of Pennsylvania bituminous coal. Syncoal ash is nonhazardous under RCRA definitions, low in heavy metals, and appears to be considerably less prone to leaching into groundwater than is incinerator ash. Michigan's Department of Natural Resources has determined that the ash may be disposed of in existing 
landfills without modification and with no need for new permits, and that the syncoal itself may be blended with coal. Co-firing with coal, particularly as a substitute for costly Western low-sulfur coal, is the major market targeted for the syncoal.

Entropic has designed a $\$ 45$ million, 630 ton/day facility it expects to construct in Pontiac, Michigan. Tipping fees for the 85 tons/day that would come from the City of Pontiac itself would average under $\$ 50 /$ ton. At full-scale operation, the plant would process fifty tons of RDF per hour in two shifts daily, 5.5 days per week, running three pyrolyzers at a $77 \%$ capacity factor. Michigan environmental groups have strongly supported this project.

Capital costs for (say) a 100 ton-per-day plant would be much less than for the 630-ton/day plant designed for Michigan. Much of the cost is for separation equipment. Costs of front-end separation equipment would be lowered considerably if arrangements can be made to share the considerable stock of separation equipment at existing Long Island incinerators and MRFs or at planned MSW composting facilities. Efficiency gains could lower costs for all parties concerned.

With such arrangements, an Entropic system could be built cheaply on Long Island. One twin-screw system, including ancillary equipment, pollution control systems, etc., could be installed on Long Island on a turn-key basis for $\$ 5$ to $\$ 6$ million in capital costs. If needed, an additional shredding unit to prepare the RDF would cost extra. A Long Island facility could process dedicated waste streams and also could provide standby or buffering capacity for other waste management facilities.

Entropic has used the technology on RDF at many localities, on auto shredder waste la melange of metal, plastic, and glass), on wastes spiked with PVC and crumb rubber, on upholstery and foam padding, and on other materials. Many of these materials came from landfills without prior front-end separation, and included rocks and dirt. Results of the landfill mining were acceptable, but it is clear that much better results would be obtained with pre-treatment screening and trommelling. The same conclusion has been reached in New York State-sponsored experiments with "mining" of old landfills by incineration and other techniques. Better pre-treatment also would reduce the ash content of the syncoal and raise its energy value.

Tires can be processed by mixing them with MSW so as to enrich the rubber content of the MSW from the baseline $2 \%$ to $4 \%$ or $6 \%$. Rubber fractions above this level may encounter difficulties in being rammed into the conveyor. The Entropic system also is highly suitable for hospital red-bag wastes. Company officials see the DOE environmental restoration and waste management programs, and federal cleanup operations generally, as a particularly important market for Entropic. The economic outlook for applications of the Entropic technology to Long Island/Northeast United States MSW is seen as particularly bright because waste tipping fees are much higher than in the Midwest.

This pyrolysis system has several distinctive features. The physically small scale of the pyrolysis units allow comparatively easy modularization, just-in-time expansion, and somewhat easier siting. The "friction-only," low-temperature heating regime lowers energy costs, simplifies engineering, and maximizes syncoal production per unit feedstock. Another design advantage is that all pyrolytic oils produced are used on-site. The low profile of the facility (the 20-foot off-gas flare stacks would be the highest part) also may facilitate siting.

Syncoal would be marketed to coal-using utilities seeking alternatives to low-sulfur Western coal in New York State (outside of Long Island), New Jersey, Connecticut, and other nearby areas. Current prices in the Midwest are $\$ 1$ per million Btu's for syncoal, versus $\$ 1.40$ per million Btu's for Western coal. Longer-distance markets may be available. The Long Island Rail Road could freight 
syncoal if a plant is built on Long Island. Emissions-trading aspects of the CAAA also may render syncoal more attractive to utilities. Syncoal ash would be incorporated into existing management systems for utility coal ash. From a regulatory and environmental standpoint, syncoal ash is easier to manage than incinerator ash.

The company has targeted several waste stream components of concern to Long Island besides MSW per se (auto shredder residue, old landfills, hospital wastes, problematic plastic resins, and tires). Officials have stated that the company is prepared to make substantial technical and capital resources available to develop a project on Long Island.

The small tube size would appear to make for easily transportable units for wastes in field locations not requiring prior sorting and shredding. Transportable Entropic units, then, appear well-suited for handling some of the relatively homogeneous wastes created in cleanup operations at DOE sites. Other cleanup wastes may be too liquid or otherwise unsuited to frictional heating, at least by themselves. Brookhaven National Laboratory could study (1) what kinds of DOE clean-up wastes have physico-chemical characteristics conducive to pyrolytic heating by mixing friction (perhaps supplemented by some externally applied heat); and, (2) what sizes of tube and screw work best with those wastes.

Entropic has been discussing possible projects involving the handling of automobile shredder waste with Argonne National Laboratory; the company has stated that should these discussions bear fruit, there would be many opportunities to dovetail projects at Brookhaven.

Hynol

Like the other pyrolysis systems sketched in this study, the Hynol system converts a flexible range of waste feedstocks into a multipurpose product -- in this case, methanol for direct use as a liquid fuel in power plants and motor vehicles, as an ingredient in reformulated, less polluting gasolines, and as a basic industrial chemical. As are other pyrolysis systems, Hynol is suited to a broad range of carbonaceous feedstocks: wood, agricultural waste (and other biomass), used oil, hazardous organic and other industrial wastes, plastics, tires, old landfills, and MSW with or without certain components removed (see below). The power production and transportation applications comport strongly with pollution reduction requirements of the CAAA and other legislation -- especially in CAAA noncompliance regions like New York City and Long Island, where increased use of oxygenated fuels is mandatory.

The Hynol system amalgamates three processes -- a hydropyrolysis step lalso called hydrogasification, this refers to purolysis in a hydrogen, or largely, hydrogen atmospherel, a steam pyrolysis step, and a methanol synthesis step.

The Hynol process was invented and developed at Brookhaven National Laboratory, building on prior BNL research, demonstration, and development efforts in biomass conversion, carbon dioxide reduction, and carbon fuel production. 
The three process steps are as follows:

Step 1: the carbonaceous feedstock is reacted at high temperatures with a hydrogen-rich gas (recycled from step 3) and high-pressure steam in a fluidized-bed hydrogasifier (HGR), yielding a mixture of carbon monoxide, methane, and nitrogen gases. The exothermic reaction that forms the methane supplies the energy for the two endothermic reactions that form the carbon monoxide. Operating conditions would be adjusted according to the nature of the feedstock: for example, $800^{\circ} \mathrm{C}$ at 30 atmospheres for biomass; $900^{\circ} \mathrm{C}$ for feedstock high in sulfur (to allow full sulfur removal by adding limestone).

Not all carbon is converted to carbon monoxide or methane: some of the feedstock would end up as char lapproximately $18 \%$ in the case of a biomass feedstock, perhaps $20 \%$ of wet weight for MSW).

Step 2: $\quad$ After particulate and gaseous impurities are removed, the gas mixture from Step 1 is combined with natural gas and reacted with steam in a steam pyrolysis reactor (SPR) at (for biomass feedstock) $1,000^{\circ} \mathrm{C}$ and 30 atmospheres, making carbon monoxide and hydrogen. The energy in the exit gas is used to heat the hydrogen-gas mixture from Step 3 for use in Step 1, and to make the high-pressure steam used in the HGR and SPR. The fraction of natural gas co-feedstock is expected to vary between $40 \%$ and $70 \%$, as dictated by the composition of the feedstock. For instance, more plastics in the feedstock means less methane; some mixed MSW feedstocks without plastics may require $70 \%$ methane fractions.

Step 3: $\quad$ Most of the carbon monoxide/hydrogen gas from Step 2 (now at $260^{\circ} \mathrm{C}, 30$ atmospheres) is converted to methanol in a conventional methanol synthesis reactor. Heat from this exothermic reaction can be used to remove feedstock moisture prior to Step 1 . The rest of the carbon monoxide/hydrogen mixture is recycled to Step 1.

The integrated system design results in energy, steam, and hydrogen self-sufficiency, high methanol production efficiency, and lower emissions capital and operating costs than with conventional processes. Net carbon dioxide emissions are estimated to be on the order of $41 \%$ lower than for standard methanol production using steam reformers.

The Hynol technology appears ready for large-scale commercialization. Reactors in each step are commercially available or have been demonstrated at large scales. Some design engineering is advisable to tailor the hydropyrolysis equipment to MSW feedstocks and to improve systems for removing impurities from gases.

Pollution reduction (and avoidance) benefits depend on what the Hynol system is being compared to -- conventional systems for making methanol from natural gas, naphtha, petroleum residues, or coal; other MSW disposal systems (incineration, recycling, composting, landfilling); other "alternative" fuels (such as methane gas or gasoline with MTBE); emissions associated with conventional gasoline and diesel fuels; or emissions associated with electricity generation from oilor coal-fired plants. In these comparisons, carbon dioxide, nitrogen oxide, sulfur, and dioxin/VOC emissions appear to be significantly smaller with the Hynol technology, although more careful assessments are in order.

Fundamental physico-chemical principles and emissions data from pilot or full-scale analogues of Hynol system components suggest that plant emissions of acid gases, sulfur compounds, nitrogen oxides, dioxins and other VOC's would be zero to extremely small (and in any 
event smaller than those from conventional methanol production facilities, and those from conventional incinerators). Heavy metals in the char are in less leachable, reduced form. Detailed information on expected char chemical composition and physical characteristics is not available.

Methanol used as automotive fuel reduces overall carbon dioxide emissions by $41 \%$ on a per-mile basis (1.5 to 2 gallons methanol substitute for 1 gallon of gasoline, depending on engine efficiency). Nitrogen oxides are not generated. The Hynol plant would produce sulfur-free methanol. All EPA regulations are satisfied by methanol utility or transportation fuel. In noncompliance areas the Clean Air Act Amendments require increased use of alternative fuels (including methanol) in vehicles (either directly or as MTBE or other oxygenated gasolines) and utilities (alone or co-fired with oil). Methanol's advantages over natural-gas fueled vehicles are that as an easily transportable liquid it meshes well with existing fuel distribution systems and engines, and that there are no methane emissions.

A consortium that has been formed to commercialize the Hynol technology seeks to build a large Hynol plant on Long Island. The consortium's preliminary calculations point to very attractive returns to potential investors. Exploratory discussions have been undertaken with some towns, utility natural gas suppliers and potential utility methane users (Brooklyn Union Gas, Con Edison, LILCO). The consortium is understood to be open as to potential sites, sources and kinds of garbage, and institutional arrangements.

One scenario is to build a facility that would accept 3,450 tons of raw MSW (wet weight, including yard and kitchen wastes) daily at $\$ 40$ per ton. After paper, plastic, and moisture removal steps, some 1,725 tons would be processed with 1,061 tons of natural gas, producing 2,500 tons of methanol and 690 tons of char ash daily. Volume reduction is projected at $80 \%$ or more (it is not clear whether this refers to MSW accepted by the facility as a whole or the MSW processed by the Hynol reactors). Capital costs are estimated to be $\$ 250$ million or less for a municipally owned, privately operated plant.

Methane would be sold to utilities for co-firing in oil-fired electric generation plants (especially for peaking power), operators of methanol-fueled fleets, and refiners as an ingredient in MTBE. A preliminary analysis has suggested an effective price lon an equivalent gasoline-miles basis) of $\$ 0.66 /$ gallon, compared to refinery gasoline prices of $\$ 0.73 /$ gallon for oil priced at $\$ 20 /$ barrel. In the event that world oil prices drop significantly and drive down methanol prices, the revenue losses could be offset by increased, but still competitive, tipping fees. In some degree prospects for methanol also depend on mileage improvements in automotive engines.

Hynol has indicated that mining old landfills (so extending the operating life of, say, the 20-million-ton Town of Brookhaven Landfill by decades, and freeing up capacity for incinerator ash and/or Hynol ash disposal), hospital wastes, and industrial wastes (including hazardous organics) are regional markets of particular interest to the company. Present expectations, though, are that MSW would be the likely linchpin of any Long Island Hynol operation. Details remain unsettled on the specific types and sources of MSW that would be sought, and on the collection, sorting, shredding, size fractionation, and other pretreatment regimes that might be employed.

A promising option for char disposal is incorporation into secondary materials, such as the construction blocks made with incinerator ash, developed by the Waste Management Institute at SUNY/Stony Brook, and the polymer encapsulation and other waste stabilization techniques developed by BNL. 
The Hynol system can process many wastes generated in DOE and other federal (and state) environmental cleanup projects. Much of the equipment and personnel resources for implementation tests and studies is in place at Brookhaven National Laboratory.

Like the Tuttle Technologies/Conrad and Pan American Resources systems, Hynol produces a keystone, multipurpose industrial chemical. An advantage of the Hynol process is that no additional refining or significant blending steps are required. Moreover, unlike the Entropic, PAR, and Tuttle/Conrad systems, Hynol can run on $100 \%$ natural gas to ride out any periods when MSW is not economically obtainable. On the other hand, unlike PAR or Tuttle/Conrad, the option of recycling the principal product of the facility into new materials (rather than fuels) is unavailable. (This is in fact technically possible, but the production infrastructure of the industrial world has been organized around petrochemicals).

A large-scale Hynol facility would be a major economic windfall for Long Island. The considerable ripple effects (construction jobs, supplier orders, etc.) would be magnified by the fact that much of the money involved would remain in regional circulation -- for example, by purchasing natural gas from regional utilities, or by converting the former Shoreham Nuclear Power Station to run on methanol. Perhaps Grumman could run the Hynol plant lor a plant using one of the other pyrolysis systems), or provide a site.

A Hynol (or a Tuttle/Conrad) facility could very well attract national attention for making a tangible dent in automotive pollution in one of the nation's most congested traffic complexes - - and for doing so with the region's own resources. That kind of attention would help national and international marketing efforts.

\section{Conrad/Tuttle Technologies}

This technology is a variant of the Conrad system, developed originally for tires, and now being modified with the assistance of the plastics industry for pyrolysis of post-consumer plastics wastes (with and without tires). In what here is referred to as the Conrad/Tuttle Technologies process, a 100 ton/day MSW-feedstock pyrolysis system produces an alternative fuel with the same properties as low octane (86) unleaded gasoline. This fuel, which runs "as is" in automotive engines, is made by blending alcohols (mostly methanol) created by the pyrolysis with Stripped Natural Gas Liquids (SNGLs). Seventy-plus percent of MSW is suitable for the pyrolysis process.

One hundred forty-five tons of MSW would be delivered 5 days per week to the Conrad/Tuttle plant. Sorting at 17 tons/hour would remove metal, glass, and other unprocessable materials, leaving perhaps 100 tons of feedstock, primarily paper, organics, and plastics, to be shredded into 2 -inch pieces. After moisture removal this material would be stored in silos equipped to prevent any build-up of gases. The shredded feedstock is fed continuously to a $540^{\circ} \mathrm{C}$ Conrad pyrolysis unit where it is converted to gas and carbon char $(6 \%-8 \%$ of the original volume). Some of the gas mixture is used as a heat source for the system, some is sent to the alcohol synthesis unit, and some is condensed to oils which in turn are sent to the alcohol unit.

The alcohol conversion plant is a standard cracking tower that produces 15,000 gallons of mixed alcohols, primarily methanol, per 100 tons of MSW entering the pyrolyzer. It receives at a pressure of 1,200 pounds per square inch the gases and oils from the pyrolyzers, stack gas, and compressor off-gas. These gases are cooled, scrubbed twice, and compressed, reheated, and steamed (providing $\mathrm{H}_{2}$ to make alcohols), catalytically vaporized, and condensed. Compressors are powered by a dedicated second pyrolyzer that would most likely be fed tires and wood waste. 
In Conrad/Tuttle Technologies' design-basis scenario, the mixed alcohol is stored for one week to accumulate 100,000 gallons for mixing with SNGLs. A site with rail, pipeline, or Interstate access (the Buckeye pipeline could be used for Long Island) is needed to receive SNGLs and to ship the final product fuel.

Depending on the chemical makeup of the MSW, the char can be landfilled lor placed in an ashfill), used in a fertilizer, or processed as activated carbon and sold.

Process parameters and environmental impacts for the steps up to and including pyrolysis are expected to be very similar to those for the earlier Conrad incarnations. In 1991, the U.S. EPA measured particulate, VOC, and other air emissions at the Conrad tire facility, as the centerpiece of a broad study of tire pyrolysis, and concluded pyrolysis units are expected to have minimal air pollution impacts because most of the pyro-gas generated in the pyrolysis process is burned as fuel in the process. During burning, the organic compounds are destroyed. Assuming complete combustion, the decomposition products are water, carbon dioxide, carbon monoxide, sulfur dioxide, and nitrogen oxides. ${ }^{4}$

The facility did not require special pollution control equipment lother than standard equipment to capture excess gas at the flare stack) or continuous emissions monitoring equipment. Emissions were well within state limits. Water pollution impacts also were judged minimal. It was found that char from scrap tire pyrolysis "does not indicate a problem with hazardous materials". ${ }^{5}$

As with the Hynol system land in certain respects the Entropic and Pan American systems), the "alternative fuel" configuration is associated with "total system" pollution and energy reductions when compared to pollution generation and energy use associated with current automotive transportation fuels. Similar Clean Air Act Amendments incentives would apply.

In the Conrad/Tuttle design, 38 million gallons of SNGLs would be purchased per year (prices have been stable $\$ 0.42$ per gallon) for blending with the alcohols. Independent (i.e., unbranded) distributors and distributor associations would market the resulting "syn-gas" marketed to local fleets -- especially government fleets complying with mandates to increase use of oxygenated fuels -- and local independent gasoline distributors. Production cost of the mixed alcohol is estimated to be $\$ 1.29$ per gallon. At the $\$ 0.42$ per gallon price for the SNGLs, production cost of syn-gas is estimated to be $\$ 0.55$ per gallon. Sale price of syn-gas at least $\$ 0.60$ per gallon. This is apart from tax incentives for creating alternative fuels.

New Jersey's refinery complexes, which are a source of SNGLs, and the allied concentration of fuel blending and distribution facilities in the metropolitan area, make the Conrad/Tuttle process attractive for the NEWME region.

Waste stream targets for the Conrad/Tuttle system, besides MSW per se, are similar to those for the other pyrolysis systems (with somewhat greater emphasis on post-consumer plastic wastes, and presumably less emphasis on tires or old landfills). The Conrad/Tuttle approach to pyrolysis shares several of the features of the Hynol approach. Both are large operations (compared to the Entropic or Pan American Resources systems) that seek to tap the regulation-driven demand

4 U.S. Environmental Protection Agency. Burning Tires for Fuel and Tire Pyrolysis: Air Implications. Report No. EPA-450/3-91-024. p. 8-13.

5 lbid., p. 8-16. 
for alternative transportation fuels, both dovetail with existing fuel preparation and distribution infrastructure, both may have need of significant on-site storage facilities.

A spreadsheet provided by Tuttle Technologies promises a $27 \%$ return on investment in year $1,35 \%$ in year $5,44 \%$ in year ten. Total 10 -year capital costs are given as $\$ 35$ million (approximately $\$ 4.2$ million in year one, $\$ 3.4$ million annually thereafter). Total 10-year operating expenses are $\$ 278$ million; these rise annually from approximately $\$ 20$ million in year one to $\$ 29$ million in year ten. Most of the operating costs are for purchase of the bulk SNGLs. Total 10-year revenue is given at $\$ 382$ million, for a total 10-year net revenue of $\$ 102$ million. Approximately thirty persons would be employed by the plant.

Capital costs per installed ton of capacity are higher for the Conrad/Tuttle system $(\$ 350,000)$ than for the Hynol 3,450 ton/day system $(\$ 72,500)$, the 100 ton/day PAR system with a new pyrolysis retort $(\$ 100,000-\$ 130,000)$, or the 100 ton/day Entropic system (minus a shredder) $(\$ 60,000)$. However, this rough-and-ready calculation ignores, among other factors, (i) the absolute size of the plant that is wanted, (ii) amortization and other financing packages, (iii) significant differences in operating costs, (iv) distinctions between costs for wastes that arrive ready for pyrolysis with minimal screening, separation, or pre-treatment -- either because some other entity has done this work beforehand, or because the wastes were collected from relatively homogeneous commercial sources to begin with -- and costs for wastes that do significantly require such measures.

The rough-and-ready comparisons of capital costs per installed ton of capacity also do not take into consideration whether recalcitrant wastes commanding higher fees, such as hospital, hazardous, or old landfill wastes, are processed.

Quoted prices are likely to come down in negotiation, (1) because representatives of the four companies have stated that their respective firms want to "crack" the Long Island market, with its dense concentration of wastes, waste facilities, and infrastructure, and so see a plant in this region as a loss leader, (2) because there would appear to be many ways to share direct and in-kind costs (and benefits) among "players" (towns, DOE, fuel companies, utilities, universities, fuel distributors, recyclers, and so on). 